\title{
Reform of the TNI and Violation of Human Rights
}

\author{
Rumadi \\ University of Wisnuwardhana Malang, \\ Indonesia
}

\begin{abstract}
After President Soeharto stepped down, ABRI was included as an institution condemned by the people, demands for self-reform emerged from all elements of society, this was also related to past wounds from ABRI's cases of actions which ultimately resulted in violations of Human Rights. The journey of the TNI Reform has been going on for about 15 years, but until now the TNI Reformation has not been successful, only a few changes in the field of policy and the loss of the political role of the TNI, the rest has not been significant (real) change. Researchers want to examine the relationship between TNI Reform and human rights violations that occurred. The initial objective was to find out if, after the TNI Reform, violations and the arbitrariness of the TNI were gone? But in the end, the researcher found the conclusion from his research that there is a very close relationship between human rights violations that still occur with informal and illegal business activities of the military. The author then re-links human rights violations with military business activities that are still reigning because of the Territorial Command structure (Koter) where military business and the Territorial Command structure are homework reforms of the TNI which until now has not yet been resolved. This research uses a historical approach by explaining the journey of TNI Reform, Human Rights, then the researcher classifies several acts of human rights violations by the army and looks for the causes of human rights violations committed by the army to civil society.
\end{abstract}

Key Words: Reformation, Human Rights Violations

\section{INTRODUCTION}

The events that occurred on May 1998, the fall of the New Order government under President Soeharto's administration were triggered by the monetary crisis in the Asian region which spread from Thailand, Malaysia, South Korea and finally Indonesia, of all countries experiencing economic crises, Indonesia is a country the worst hit by the crisis is the sharp drop in the US dollar. Because the economic system in Indonesia does not have a strong enough foundation, the solution is not getting good results, it is even more protracted and the rupiah is plummeting. This brought the impact of the government's low credibility and the people began to lose confidence.

Since the fall of the New Order under President Soeharto by the student movement in the name of the reform movement, ABRI's position on the Indonesian political map has also fallen. It cannot be denied that ABRI is a political power of the New Order together with Golkar. The fall of the New Order meant the fall of the Armed Forces as a buffer for the government because the Armed Forces during the New Order were more identical to the government tools in power than the Armed Forces in the Indonesian political map. It cannot be denied that ABRI is a political power of the New Order together with Golkar. The fall of the New Order meant the fall of the Armed Forces as a buffer for the government because ABRI during the New Order was more identical to the tools of the ruling government rather than the means of buffering and protecting the country from all external threats through the dual concept of ABRI's functions. ABRI is urged to carry out reforms, although in broad outline there are a number of reasons that become the background of TNI Reform, not only because of the dual functions of ABRI.

Development programs in the New Order era were launched through the concept of the Development Trilogy, namely: (1) Equitable Development and its results towards the creation of social justice for all Indonesian people; (2) High economic growth and (3) Healthy and dynamic national stability. In "stability" that is contained "security approach". Dwi's practice The function of ABRI became fertile since the New Order, namely by implementing the "security approach". This security approach is implemented in view of two things, namely: First, the post-G30S / PKI 1965 atmosphere still requires the implementation of all forms of security activities in all sectors and throughout the Republic of Indonesia from the latent danger of communism. Second, the New Order is determined to implement a development program whose success demands security stability. From the practice of 
the dual functions of the Armed Forces at that time evolved militarism (the power and State Government lay in the military) and militarization (the military entered into government).

Various acts of violence committed by the state by using ABRI as its instrument must end, militarism and militarization must end. ABRI must return to its professionalism. The people themselves should not be treated as enemies. The state must be able to defuse any turmoil in society without having to kill the people themselves. All turmoil must be resolved politically without involving the military and military violence and without having to violate human rights.

ABRI's tendency to prioritize and maintain power brought ABRI trapped in repressive patterns of approach. So it is not uncommon for ABRIs to act out of their hands to say every Apple or Ceremony, namely the Sapta Marga and the Oath of Warriors. Violations in various forms, both criminal and political motives, are increasingly accumulating. So that at the right moment, when the fall of the New Order government, all the accumulated violations of ABRI in the past exploded. ABRI was hated and blasphemed by the people because it was considered more as a protector and safeguard of the New Order for 32 years than as a protector and protector of the people.

\section{LITERATURE REVIEW}

\subsection{Definition of Military and Civil}

In English, Military or "military" is "the soldiers; the army; the army forces "which means soldier or army; armed Forces. In modern countries, the military is usually an armed force consisting of 3 armies, namely: land, sea, and air. While the police, although given the authority to hold weapons, are not included in it. Civil parties can be the general public, government, and private institutions, politicians and statesmen [1]. Sayidiman Suryohardiprojo provides civil restrictions as all strata of society [2].

\subsection{Theories about Human Rights}

Human rights can be divided or distinguished as follows [3]:

a. Personal rights or "personal rights" which include freedom of expression, freedom of religion, freedom of movement and so on.

b. Economic rights or "property rights", namely the right to own something, buy and sell it and use it.

c. Human rights to get equal treatment in law and government or "rights of legal equality".

d. Political human rights or "political rights", namely the right to participate in government, the right to vote (vote and be elected in general elections), the right to establish political parties and so on.

e. Social and cultural rights or "social and cultural rights", for example, the right to choose education, develop culture and so on.

f. Human rights to obtain treatment and procedures for justice and protection or "procedural rights", for example, regulations regarding arrest, search, justice and so on.

\section{RESEARCH METHODS}

\subsection{Types of research}

This type of research used in this study uses descriptive research with the aim of describing, summarizing various conditions, situations or various variables that arise in the community that is the object of research. This descriptive study uses a historical approach. This descriptive method uses theories related to TNI Reform, civil-military relations and Human Rights.

\subsection{Data collection technique}

The data and information collection techniques in this research is to use the method of library research or library research that is by collecting books, papers and documents from various sources and places as well as other things that support and also do some research and discussions with various parties, then if necessary interviews are also conducted with related parties in order to perfect this research.

\section{DISCUSSION}

\section{Types of human rights violations committed by the authorities}

Every country has its own "package of human rights violations" [4]. It is clear that there is no country where human rights violations have never occurred. What is important is that there are efforts to sensitize the public, monitor violations and make continuous corrections. According to the quantity of human rights violations reported to the National Human Rights Commission, the types of human rights violations that occur most in a row are: land disputes, labor cases, cases of dishonorable acts by state officials in the form of human rights violations, housing cases and cases religious fields [5].

Based on the main issues in the KontraS (Commission for Missing Persons and Violence) since the 1998 Reform took place, there are four issues and classification of types of human rights violations committed by the TNI, namely: 
1) Torture

Namely Torture which means every action done intentionally, causing great pain or suffering, both physically and spiritually to a person to obtain confession or information from someone or from a third person, by punishing him for an action that has been done or is suspected to have been done by a person or third person, or threatening or forcing a person or third person, or for a reason based on any form of discrimination, if the pain or suffering is caused by, incitement from, with the consent of, or the knowledge of anyone and or public officials.

2) Ekstra Judicial Killing

Namely Murder outside the legal procedure. Can be interpreted as an act of vigilantism. Because Indonesia is a state of law, everything that is done that is not in accordance with the law or not with the legal process can be said to be something that is outside the legal procedures and violates human rights. In accordance with Law No.39 / 1999 concerning Human Rights Article 33 (2) which reads: "Everyone has the right to be free from enforced disappearance and loss of life".

3) Enforced Disapperances

Namely the disappearance of people arbitrarily. Abduction of people by force and not returning, these abductions are classified as arbitrary because they do not have an appropriate legal basis. Arrest, detention, exile, and disposal of people arbitrarily contravenes Law No.39 / 1999 concerning Human Rights Article 34.

4) Use of excessive authority

That can be categorized as ways or excessive actions of authority and obligations that should be carried out by the TNI in the field such as: arrest, terror and intimidation, shootings, mistreatment and beatings, forced land taking, fraud or extortion, embezzlement, destruction, trafficking, search without legal procedures, demolition of houses and others.

Actually there are many more examples of human rights violations committed by the authorities but are classified into 4 main issues, which means that the authorities here are a body or bureaucracy that in carrying out its duties is given authority by the state to carry out acts of violence / repressive. Why did the writer take 4 main issues on KontraS? Because the authors feel, KontraS as a non-governmental organization that focuses its attention is concerned with human rights and acts of human rights violations committed by the authorities, namely: TNI, Polri, Satpol PP, and others.

\subsection{Informal and illegal business as the dominant factors causing human rights violations by the TNI}

Based on the study obtained by the author, Human Rights Violations after TNI Reform still exist and Military Business is the dominant factor in the occurrence of Human Rights Violations committed by TNI Institutions. Before further elaboration, the author first wants to explain briefly first of all including the classification of military military business activities. There are so many parties who classify the types of TNI businesses, but the authors raise the classification of TNI businesses by means of an explanation from ICW.

Classification of TNI Military Business Activities, are:

1) Formal Business

Is a category for business that involves the TNI institutionally in business. An example is a military business in the form of foundations. The composition of the foundation's management follows the command structure. Thus this business is owned by military institutions, especially the unit of command or headquarters concerned. Business in the form of a foundation is not only run at the unit level or at the Headquarters level. In the military hierarchy below, like Kodam, it also has its own foundation. Another form of formal business is cooperatives. Cooperatives in the military environment also follow the command structure. At the Headquarters level (Headquarters), cooperatives use the name Parent, while at the Kodam level, cooperatives use the name of the Center and at the Korem or Kodim level, Primary names are used.

2) Informal Business

Is a military business that does not involve the military as an institution but on behalf of individuals. Can be active military personnel, retired military personnel, family members of active or retired military personnel or cronies of active and retired military personnel. Can be in the form of share ownership in a private or state-owned company or in the form of developing their own business

3) Illegal / Criminal Economy Business

Is a military business as a form of abuse of military authority. Usually in the form of protection services provided by military members of illegal business that violates the law. For example: narcotics trafficking; demonstrator service provider; bekking gambling, prostitution and others; illegal logging and others. [6]

Business activity as stated in the above classification is actually not the only source of military funding outside the official budget. There are still various other sources that also produce relatively the same benefits as gifts and work commissions and money quotes on the road in operations in conflict areas and so on. This description of military business activity can also be seen from the composition of the budget and defense financing, although the amount of donations only the TNI knows.

The myths that are the background of the TNI in business are: 1). The budget allocated by the government can only cover a small amount of funding from the total budget needed by the military; 2). That the military business that is carried out 
significantly covers the gap in military financing; 3). Most of the proceeds from military businesses are used to meet the welfare of soldiers.

These myths can never be fully justified because, in the case of lack of budget, the stated statistics are often not actual figures. There is no comprehensive data describing all TNI revenues, including those originating from non-APBN financing sources such as funds for security operations, terrorism, natural disaster management, export credit and funds sourced from the APBD as in the activities of the Manunggal Men entering the village (which also accepted by the TNI even though it contradicts the TNI Law and the National Defense Law). It is estimated, if calculated and used carefully, the whole fund can gradually meet the financial shortcomings. In the case of businesses to cover the gap in military financing, the contribution made by military business units in recent years is very insignificant. A number of military foundations' businesses were reported to have lost money, had debts with third parties or were declared closed. While businesses that are intended to meet the welfare of soldiers through foundations and cooperatives are, on average, at a loss and are only benefited by a handful of military officers. In some business units, the commanders of the business owner institutions are free to decide on the policy to use profits without an accountable record and beyond the purpose of meeting the common welfare.

Reform demands that the TNI go out of business. The Indonesian Corruption Watch (ICW) study noted three arguments that caused the TNI to go out of business. First, the freedom of expression enjoyed by the military by having independent sources of funding has weakened the government's ability to set national goals and ways to achieve them. Second, the time and energy absorbed in organizing and carrying out business activities distracts the attention of the army and military personnel from state duties, namely to defend the country against external threats and strengthen domestic security. Third, military business activities create distortions in the national economy and hamper its growth by reducing productivity and misallocation of scarce resources. Easy access to bank credit is a damaging character of TNI businesses. This also impedes the growth of a fair market mechanism, where the military as a party becomes a competitor who uses its power and networks in the business area.

As an institution that has the authority to use violence, the existence of military business not only creates economic distortion but also has the potential to violate human rights and threaten democracy.

Starting from the TNI business, then the TNI is involved directly or indirectly in violations and serious crimes of Human Rights both politically and economically, socially and culturally. Forced events (evictions) for example: international human rights law expressly includes acts of forced eviction as gross human rights crimes. Because these actions are always synonymous with intent.

In addition, the consequences of these actions have serious consequences on the victim. Among others; loss of property, physical suffering due to frequent use of violence, therefore in the instrument of social and cultural economic rights, this act was declared a grave crime of human rights. Indeed in some cases, forced evictions are justified by the United Nations, but must fulfill several procedures; issued an announcement six months before the eviction, opened space for debate about the plan, there were negotiations on the parties to be evicted, giving compensation in accordance with the wealth of the parties to be evicted.

So, it is certain that for the moment the TNI gap in military business has made possible human rights violations. In fact, the military business does not answer their problems, because most of the results of the military business are only enjoyed by highranking officers, not by the army. This is only a "side effort" among the elite at the General level, starting from the rank of Major and above or middle-ranking officers. And the facts show that military businesses that often allow human rights violations are informal or even illegal military businesses.

The high level of violence according to the observation is at least influenced by two factors; First, the strength of local government organizers and the security forces (including the TNI) to support investors or capital interests. This partisanship caused some people to lose their ability to access health, education, housing, and even work. The irony of this partiality is that it also causes the community to experience a process of dehumanization (making humans not by nature) and marginalization (marginalizing). Second is the absence of human rights protection institutions. Reorganization of local government structures (autonomy) through Law No. 22 of 1999 and law No. 32/2002, was not accompanied by the construction of institutions for the protection and enforcement of human rights. Even synchronization of a number of regional regulations with national human rights law is not found.

\subsection{The Importance of Abolishing Military Business as a Complete Effort of TNI Reform}

Now we have come to the conclusion that the TNI must go out of business, all that's left is to technically get the TNI out of business. The problem of taking over TNI businesses lies in three things. First, the problem of the obscurity of definition. Second, weak and visionary regulations reflect political aversion. Third, the issue of budget myths that are believed to be unable to replace the TNI's off-budget costs obtained from direct or indirect business.

Since the beginning of the issuance of Law No. 34 of 2004 concerning the TNI, then in article 76 paragraph 1 clearly stated "within the period of 5 (five) years from the enactment of this law, the government must take overall business activities owned and managed by the TNI, both directly and indirectly ". The problem starts from here, because there is no clear definition of the TNI business, how the business is said to be managed and owned directly and indirectly. According to Makmur Keliat, "The big problem going forward that must be immediately resolved at an early stage is to agree on what is meant by the military business."

The ambiguity of this definition led to the blurring of the performance of the TNI Business Transformation Supervision Team (TSTB) formed in mid-2005 because many of the TNI businesses took the form of foundations and cooperatives. Confusion also occurred when TSTB tried to classify TNI businesses managed through equity participation and businesses that involved 
individual TNI or retired officers. This blurring continues with the performance of the National Team for Transferring TNI Business Activities, which was formed through Presidential Decree No. 7 of 2008.

Another blur arises when this regulation does not specifically explain its conflict with Law No. 12/2001 concerning Foundations and Law No. 25/2002 on Cooperatives, where the TNI business with its various specialties has run its business also through cooperatives and foundations so that there is confusion. These ambiguities are further complicated by the slow response of the government in realizing the mandate of the TNI Law. TSTB was only formed in mid-2005, for a year later the team only reported various obstacles without a clear solution. According to this team, "Indeed, the estimate is January. We have sent a letter requesting funds to the managers with the deadline of January 31 at the latest. But after entering into technical problems it seems that gathering data is quite heavy, so the team that will be proactive will come."

After years without clear news about the progress of TSTB's work, the president issued Presidential Decree No. 7 of 2008 concerning the formation of a National Team for the Transfer of TNI Business Activities. According to some teams, this team is repeating what TSTB has done, as well as the very limited authority given to this team. In Keppres this team has three main tasks:

1) Conducting assessments which include inventorying, identifying, and grouping all business activities that are owned and managed by the TNI, directly or indirectly;

2) Formulating policy steps in the context of transferring business activities owned, controlled and managed by the TNI, both directly and indirectly for the completion and / or subsequent management to be arranged in accordance with the provisions of the legislation in force;

3) Provide recommendations for policy steps to the President in the context of transferring business activities owned and managed by the TNI, directly or indirectly, to the Government.

This means that this team does not have the authority to carry out direct military business takeover, because that authority must be returned to the President. Seeing the work period given by the President to this team until October 2009, the takeover of TNI businesses cannot be done until 2009, because what will be produced by this team is only in the form of recommendations to the President. And until now we can see the stagnation of this military business transfer journey.

Therefore, in order to solve these problems, quick and anticipatory steps need to be taken immediately, including:

1) The government must immediately make a regulation and implementation instructions and through clear, consistent stages as mandated by article 76 of Law No. 34 of 2004 concerning the TNI. The DPR and DPD as institutions that carry out the control function must keep an eye on the process.

2) The Government and Parliament must realize that taking over TNI businesses is an urgent task that must be completed because this is the result of their political decisions. In addition, the government and the DPR must immediately meet the ideal budget as a consequence of the takeover of TNI businesses.

3) TNI must be placed in its initial position as an institution that deals with the defense and must not be involved in politics and business. The government and the House of Representatives must not try to drag them into politics or let them live in the business world.

\section{CONCLUSION}

Human rights violations by the TNI, classified by KontaS according to their main issues, are 4:

1. Torture or torture;

2. Extra Judicial Killing or extrajudicial killings;

3. Enforced Dissaperance or disappearance of people arbitrarily;

4. Use of excess authority.

And all of this in Human Rights law is a gross violation of human rights as explained in article 7 letter b of Law No.26 / 2000 concerning human rights court.

TNI reform has a very noble goal of becoming a Professional, Effective, Efficient and Modern Army (PEEM). Professional soldiers, namely: trained, educated, well-equipped soldiers who are not involved in practical politics, do not do business and are guaranteed welfare, and follow state political policies that adhere to the principles of democracy, civil supremacy, human rights, national law, and international law has been ratified. In accordance with Law No.34 of 2004 concerning the TNI.

Of the three classifications of military business activities, namely formal business, informal business and illegal business / criminal economy, the reality is obtained by the author that informal business and illegal business / criminal economy are the main indications of human rights violations by the TNI. So, this business does not carry the name of a foundation or cooperative, even though it still carries the name of unity or in person.

Human rights violations that still occurred throughout 2008 to March 2013 were the use of excessive authority such as terror and intimidation, persecution, eviction, and related to crime such as drug sales and fuel hoarding. And that's because informal business and illegal personal or unity.

To be able to realize a professional army, the military must have a great spirit to leave all its business activities, and let civilians handle and manage what is part of it. And it is also the duty of the state to guarantee the welfare of all its citizens including 
adequate and adequate military survival not only from salaries, side dishes, various benefits but also from housing and also equipment. So that when the military has led to its professionalism, Objective Civil Control can be implemented and achieved.

In the end, the TNI Reform that was carried out seriously in accordance with the prevailing system would give birth to professional soldiers who had characteristics; (1) not engaging in politics and business, (2) Having expertise, professional unity, technical competence, and knowing exactly military ethics and war ethics, (3) Respecting Supremacy, law, democracy and Human Rights and (4) when the army was deployed for use, successfully won the war.

\section{SUGGESTION}

1. Speed up the resolution and decisive action in every illegal military business activity. And the President as head of state is the only party that can expressly take over all TNI business activities and even has the authority to stop all military business activities. So it requires decisiveness by the Head of State to truly discipline the TNI. And as a consequence, the government needs to prepare an allocation of additional state budget funds to improve the welfare of TNI members.

2. One of the most fundamental reasons for the involvement of the army in business is that the state is unable to provide sufficient budget. So far the state budget has only been able to cover $30 \%$ of the TNI's needs. Unfortunately, the military itself is not aware when talking about the budget, it should first formulate the basic problems of defense and what threats will be faced. From the definition of the threat, the army posture will be formulated as what is needed to counter the potential threat. Only then after the army posture is formulated, how much budget is needed. Furthermore, the budget needs will be divided again into a number of priorities. Because it is impossible for the country to fulfill all needs at one time. Therefore, the desired army posture must be planned in the short-term, medium-term and long-term strategies. And the next problem in the military is budget allocation. The biggest budget allocation is precisely allocated to the Army. Even though geographical conditions such as Indonesia, many military observers say that the largest portion of the budget allocation should be given to the Navy to maintain along the coastline outside Indonesia which is actually the largest archipelago. And this is the duty of the Department of Defense to make clear and standard boundaries of the nature of the threat, and also actively recommend to the President and the TNI Commander in order to allocate funds in accordance with existing plans.

3. Rearranging the territorial command-based defense system that prioritizes defense on the Army dimension, bearing in mind that Indonesia is actually an archipelagic country with thousands of islands in the outline and is not named so it would be better to strengthen the defense also in the Navy and Air Force.

4. TNI should be equipped with a more mature understanding and learning about human rights and humanitarian law. This will indirectly affect the mindset of soldiers about what is feasible and not worth doing by them. The important task of the TNI is to improve the culture of each of its personnel to the lowest level. This includes improving their mindset about military business, human rights violations, and TNI Reform. Awareness and obedience to Law and Human Rights, Discipline of soldiers who are free from arrogance, as well as many habits that were formed during the period before the reform. Which could lead to many clashes on the ground because of his attitude and arrogance.

5. There is transparency to the state and the public in terms of the income and expenditure of foundations and cooperatives under military institutions so that no corrupt practices are carried out by high-ranking officers who prioritize individual interests and do not even pay attention to the interests of their soldiers.

6. Renew the system of military leadership positions. Comprehensive bureaucratic reform to eliminate Corruption and bribery to military leaders who get "wet" or high positions.

7. There is also transparency to the public over efforts to resolve various cases involving civil society, transparency in military courts, with the openness of military justice and the completion of the Military Justice Bill so that there are no more practices of impunity so that the creation of military institutions that are accountable and truly respect human rights.

\section{REFERENCES}

[1] Elliot A. Cohen, "Civil-Military Relation in the Contemporary World”, dalam Susilo Bambang Yudhoyono, Pengaruh Internasional dalam Hubungan Sipil - Militer, sebuah makalah yang disajikan dalam seminar nasional mencari format baru Hubungan Sipil-Militer Jurusan Ilmu Politik - Fisip Universitas Indonesia, Jakarta, 24-25 Mei 1999, Gedung Pusat Studi Jepang, Kampus UI Depok.

[2] Sayidiman Suryohadiprojo, Hubungan Sipil-Militer di Indonesia: Suatu Pembahasan, Sebuah makalah yang disajikan dalam Seminar Nasional Mencari Format Baru Hubungan Sipil-Militer, Jakarta : FISIP UI, 1999

[3] Kansil, C.S.T, Hukum Tata Negara Republik Indonesia, Jakarta : Penerbit Rieka Cipta, 2000.

[4] Bahar, Saafroedin, Hak Asasi Manusia : Analisis Komnas HAM dan Jajaran Hankam/ABRI, Jakarta : Pustaka Sinar Harapan,1996.

[5] Komisi Nasional Hak Asasi Manusia, Laporan Tahunan 1994, Jakarta : Sekretariat Jendral Komnas HAM.

[6] Tim ICW, Bisnis Militer Mencari Legitimasi, Jakarta : ICW, 2004. 